\title{
EDITORIAL
}

\section{Enfrentar el cambio climático es un desafío para la civilización actual}

\author{
Facing the climate change is a challenge for the current civilization
}

Juan Francisco Trevizan Rispoli
Facultad de Ciencias Agronómicas
Universidad de Tarapacá

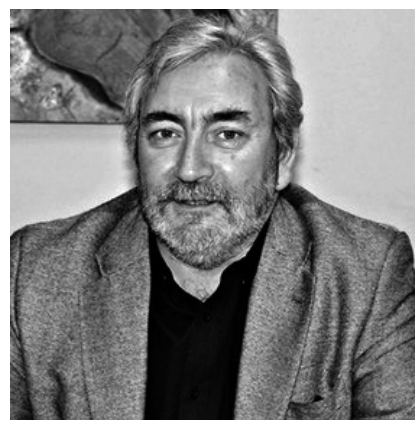

Juan Francisco Trevizan Rispoli

Faculty of Agricultural Science

University of Tarapaca
"Produce una inmensa tristeza pensar que la naturaleza habla mientras el género humano no la escucha".

Víctor Hugo (1802-1885)

Desde su creación -hace 25 años- se realiza anualmente la Conferencia de las Partes (COP) de la Convención Marco de Naciones Unidas para el Cambio Climático (CMNUCC), la cumbre sobre el cambio climático más importante del mundo. Allí se reúnen representantes de alto nivel de 197 países para impulsar políticas activas que protejan al planeta de los efectos de la crisis del clima. La cita de este año, la COP25, será entre el 2 y 13 de diciembre en España.

En junio pasado los estados miembros de la CMNUCC se sentaron a negociar durante dos semanas, en Bonn, Alemania. El cierre de la última jornada de la sesión intersesional se extendió hasta cerca de la medianoche y el salón plenario se repletó de poleras blancas con la consigna "la ciencia no se negocia".

Según la prensa, en Bonn no faltó la polémica entre las partes, en un escenario diplomático pero tensionado que probablemente se repetirá en la COP25, donde se negociará el reglamento que determine la aplicación del Acuerdo de París, el tratado internacional más importante en la lucha contra el cambio climático, celebrado en la COP21
"How sad to think that nature speaks and mankind doesn't listen."

Víctor Hugo (1802-1885)

Since its creation - 25 years ago - the Conference of the Parties (COP) of the United Nations Framework Convention on Climate Change (UNFCCC), the most crucial climate change summit in the world, is held annually. There, high-level representatives from 197 countries meet to endorse active policies that protect the planet from the effects of the climate crisis. This year's appointment, COP25, will be held between December $2^{\text {nd }}$ and $13^{\text {th }}$ in Spain.

Last June, the member states of the UNFCCC gathered to negotiate for two weeks, in Bonn, Germany. The closing of the last day of the intersessional session lasted until about midnight, and the plenary hall was filled with white t-shirts with the slogan "science is not negotiable."

According to the press, in Bonn the controversy between the parties was not absent, in a diplomatic but stressed scenario that will probably be repeated at COP25, where the regulation determining the application of the Paris Agreement, the most important international treaty in the fight, will be negotiated against climate change, held at COP 21 in 2015. Just like any other law, the treaty will not be a law without its regulation, which has been discussed for the last four years. 
en 2015. Tal como cualquier ley, el tratado no será ley sin su reglamento, que es lo que se ha discutido en los últimos cuatro años.

La cita en Alemania debía dejar avanzado el texto final para llegar a la COP25 a negociar, pero las diferencias provocaron que solo quedaran consignados algunos avances en los borradores. Por lo tanto, el grueso de la discusión será en esta cumbre.

El Acuerdo regirá a partir del año 2020 y la COP25 será la última oportunidad de ajustarlo para su aplicación.

Por lo adelantado en Bonn, la cumbre no debiera ser una negociación, sino una instancia que lleve a líderes políticos a comprometerse ante el mundo a generar mayores acciones en la lucha global contra el cambio climático, que ya no admite cuestionamiento, pero desafía a nuestra civilización y sus mecanismos de acuerdo (la inteligencia colectiva a través de sus organizaciones) a tomar las mejores decisiones para enfrentarlo.

Los cuatro grandes temas que abordará la COP25 son los mercados de carbono, ¿quién paga por los daños de los desastres naturales?, las metas de reducción: ¿Cada cinco o diez años? y el rol de la ciencia Respecto a este último punto, el Panel Intergubernamental de Cambio Climático (IPCC), que reúne a científicos de todo el mundo, publicó un documento técnico sobre el estado del cambio climático, que señala que desde la era preindustrial hasta hoy, la temperatura ha aumentado en $1{ }^{\circ} \mathrm{C}$, lo cual ya está generando grandes impactos a nivel ecológico en el planeta. Por ello, el IPCC enfatizó que es necesario limitar el aumento de la temperatura a $1,5^{\circ} \mathrm{C}$ al año 2030 si queremos conservar el mundo muy parecido a como lo conocemos hoy, ya que con $2{ }^{\circ} \mathrm{C}$ o $3{ }^{\circ} \mathrm{C}$ se incrementarían considerablemente los eventos meteorológicos extremos, la pérdida de especies, la escasez de agua y alimentos, entre otros, afectando principalmente a las poblaciones más vulnerables.

Para limitar el aumento de la temperatura a nivel global, según el IPCC, existe la urgencia de alcanzar la "carbono neutralidad" al 2050. Ante esto, es necesario que tomemos en cuenta que los gases de efecto invernadero que ya hemos emitido se mantendrán por siglos en la atmósfera, acelerando el calentamiento global.

Tomar una postura de neutralidad ante las presiones de países que se oponen a cooperar (siendo ellos los mayores responsables de las emisiones de gases de efecto invernadero), para alcanzar las
The appointment in Germany had to advance the final text to reach the COP25 to negotiate, but differences caused that limited progress was recorded in the drafts. Therefore, the majority of the discussion will be at this summit.

The Agreement will be effective as of 2020, and COP25 will be the last opportunity to adjust it for its effect.

In advance in Bonn, the summit should not be a negotiation, but an instance pointing to political leaders to commit themselves to the world to generate significant actions in the global fight against climate change, which no longer admits questioning but defies our civilization and mechanisms of agreement (collective intelligence through its organizations) to make the best decisions to face it.

The four major issues that COP25 will address are carbon markets, who pay for the damage of natural disasters? Reduction goals: Every five or ten years? and the role of science. Regarding this last point, the Intergovernmental Panel on Climate Change (IPCC), which brings together scientists from around the world, published a technical document on the state of climate change, which indicates that from the pre-industrial era to present days, the temperature has increased by $1 C$, which is already generating significant impacts at an ecological level on the planet. Therefore, the IPCC emphasized that it is necessary to limit the temperature increase to $1.5^{\circ} \mathrm{C}$ by 2030 if we want to keep a world similar to what we know today considering that with $2{ }^{\circ} \mathrm{C}$ or $3{ }^{\circ} \mathrm{C}$ extreme weather events would increase considerably, the loss of species, water and food shortages, among others, mainly affecting the most vulnerable populations.

To limit the increase in temperature globally, according to the IPCC, there is an urgent need to achieve "carbon neutrality" by 2050. Given this, we must take into account that the greenhouse gases that have been already emitted will be maintained by centuries in the atmosphere, accelerating global warming.

Taking a neutral stand facing pressure from countries that are opposed to cooperating (being the ones most responsible for greenhouse gas emissions), to achieve the goals set by the scientific world in the IPCC report, is not the way before a crisis that is becoming more latent, and that will end up affecting millions of people. Although in the collective conscience, the premise "the polluter 
metas planteadas por el mundo científico en el informe del IPCC, no es el camino ante una crisis que se hace cada vez más latente, y que terminará afectando a millones de personas. Y aunque en la conciencia colectiva la premisa "el que contamina paga" se considera ley, en la práctica la pagarán especialmente los países y poblaciones más pobres que cuentan con menos recursos para adaptarse al cambio climático.

Se hace necesario por parte del mundo científico, incluyendo las ciencias políticas, poner en cada uno de los ámbitos de injerencia la voz de alerta y proponer las acciones tendientes a generar las condiciones que permitan trabajar aspectos de sustentabilidad asociados a la mitigación y adaptación de lo que hoy ya vemos como una realidad.

Ante este gran desafío debemos tomar en cuenta que ninguna acción por pequeña que sea deja de ser importante.

Que debemos poner el ser por sobre el tener. pays" is considered the law, in practice, it will be paid especially by the poorest countries and populations that have scarcer resources to adapt to climate change.

It is necessary for the scientific world, including the political sciences, to put in each of the areas of interference the alert voice and propose the actions tending to generate the conditions that allow working on matters of sustainability associated with the mitigation and adaptation of that today is seen as a reality.

Facing this great challenge, we must take into account that any action, however small, is no longer irrelevant.

We must put being above having. 